acid excretion and creatinine clearance was low, being $290 \mathrm{mg} /$ day and $37 \mathrm{~mL} / \mathrm{min}$ respectively. Additional abnormal investigations included a haematocrit of $27.3 \%$, urea of $30 \mathrm{mg} / \mathrm{dl}$, ESR of $78 \mathrm{~mm} / \mathrm{h}$. Serum trigliceride and total lipid were elevated being $291 \mathrm{mg} / \mathrm{dl}$ and $1281 \mathrm{mg} / \mathrm{dl}$ respectively. On USG bilateral soft tissue swelling in the axillar region were found to be compatible with lipomatosis. Urolithiasis was not observed. With these findings and family history she was suspected to have hereditary familial hyperuricemic nephropathy.

After resolution of the acute attack with indomethacin, allopurinol treatment was started but had to be discontinued upon occurrence of widespread erythematous rash. She was hospitalised and desensitisation regime lasting 10 days was commenced. After desensitisation, she was free of symptoms with $300 \mathrm{mg} /$ day allopurinol and $0.5 \mathrm{mg} /$ day colchicine. Four months later, she developed oral ulcers. Since there was a doubtful genital ulcer history she was examined for Behçet's disease. Pathergy test was negative and unexpectedly she was HLA B27 positive but no other signs suggesting spondyloartropathy was present. Oral ulcers disappeared after allopurinol dosage has been lowered to $150 \mathrm{mg} /$ day, the rash or ulcers has not recurred. The tophii were dissolved, renal functions and blood pressure have not deteriorated over time, there has been dramatic improvement of her symptoms with normalisation of serum urate levels, she is now Steinbrocker class II.

Results

Conclusion Hyperuricemia or gout appearing at an early age in a female is usually associated with progressive renal failure. Early recognition of this disorder is important since allopurinol therapy may ameliorate the progression of the renal lesion. In cases of hypersensitivity to allopurinol oral desensitisation is a feasible approach.

\section{AB0156 THE EFFICACY OF ALENDRONATE IN POSTMENOPAUSICAL OSTEOPOROSIS}

1J Fernández-Melón, ${ }^{1} \mathrm{M}$ Bernad, ${ }^{1} \mathrm{~A}$ García-Aparicio, ${ }^{1} \mathrm{G}$ Bonilla, ${ }^{2} \mathrm{ML}$ Gonzalez, ${ }^{3}$ ME Martinez, ${ }^{1}$ E Martín-Mola. ${ }^{1}$ Rheumatology; ${ }^{2}$ Biochemistry Service, Hospital Gomez Ulla, Madrid, Spain; ${ }^{3}$ Biochemistry Service, Hospital La Paz

\subsection{6/annrheumdis-2001.478}

Background This is a prospective study of bone mineral density in postmenopausical women treated with alendronate.

Objectives To evaluate the efficacy of alendronate in postmenopausical osteoporotic women for 1, 2 and 3 years.

Methods In a prospective study, we included 98 women diagnosed of postmenopausical osteoporosis attended from 1997 to 2000. The mean age was 59.07 (SD: 6.68). Patients received alendronate $10 \mathrm{mg}$ daily, they were allowed to take calcium and vitamine $\mathrm{D}$ supplementation. The subjects were assessed at baseline, 12, 24 and 36 months for bone mineral density (BMD) measurements and X-ray and every 6 months blood and urinary biochemistries and markers of bone turnover were done.

Results Sixteen patients (16\%) have dropped out because of adverse effects, the most common was gastrointestinal events. 34 $(34.6 \%)$ patients had previous fractures (17 had spine fractures, 12 Colles's fractures and one hip fracture). Three patients on treatment with alendronate had new fractures (1 spine, 1 scaphoid and one Colles's fracture). 70, 24 and 7 subjects have completed one, two and three years of treatment, respectively. The results were analysed by Student's t-test. Patients treated with alendronate for 1 year had significantly greater improvement in BMD at spine. The mean BMD at baseline was 0.373 vs $0.773(\mathrm{p}<0.005)$ and at hip 0.665 vs 0.643 at baseline $(\mathrm{p}<$ 0.005). Patients who completed two years had similar values of $\mathrm{BMD}$ as the year before, the mean BMD was 0.745 at spine and 0.646 at hip.

Conclusion Patients treated with alendronate for one year had significantly greater improvement in BMD at both the spine and hip.

\section{AB0157 PARANEOPLASIC HYPERCALCEMIA COMPLICATING A B CELL NON-HODGKIN LYMPHOMA (NHL)}

E Karoubi Nordon, E Palazzo, SA Rouidi, O Meyer. Rhumatology, BICHAT, Paris, France

\subsection{6/annrheumdis-2001.479}

Background Hypercalcemia is an unfrequent manifestation of $\mathrm{B}$ cell NHL. We describe a case report of hypercalcemia secondary to PTH-rp production, inaugurating a B-cell NHL.

Objectives A 77 year old woman was admitted with dorsalgia. Physical examination was negative except neuropsychological hyperexcitability.

Biological data rrevealed an increased calcemia $(4.2 \mathrm{mmol} / \mathrm{l})$ with decreased phosphoremia $(0.45 \mathrm{mmol} / \mathrm{l})$ suggesting a hyperparathyroidism. However, PTH(RIA) was low $(3.5 \mathrm{pg} / \mathrm{ml}, \mathrm{N}=$ 11.0-62.0) and $1.25(\mathrm{oh}) 2 \mathrm{~d} 3$ level was in the normal range $(40$ $\mathrm{yg} / \mathrm{l}, \mathrm{N}=15-80)$. PTH-rp was moderatly increased (2.1 ymol/l, $\mathrm{N}<1.5$ ). Bone marrow aspiration was normal. No sign for osteolysis was present on bone X-ray, CT scan and MRI. The abdominal CT scan and abdominal MRI revealed a retroperitoneal mass. A needle biopsy was diagnostic for NHL B type. LDH were elevated to $3290 \mathrm{U} / \mathrm{l}(\mathrm{n}<470)$. Other lymphoid tissue involvment was limited to the spleen. IV farmidronate was successfuly adminitred for treatment of hypercalcemia.

Methods

Results Malignat hypercalcemia occurs in 14p.cent of leukaemia and lymphoma. Among NHL, T cell lymphoma positive for HTLV-1, are more frequently associated with hypercalcemia mediated by production of $1-25(\mathrm{OH}) 2 \mathrm{D} 3$ or lymphotoxin/OAF. Less than 3 p.cent of B cell NHL are associated with a paraneoplasic hypercalcemia. Two hypercalcemic mediators have been caracterised: PTH-rp and/or OAF

Conclusion Humoral hypercalcemia mediated by PTH-rp is a rare complication of $\mathrm{B}$ cell-NHL. Hypophosphatemia with a decreased PTH plasma level must alert for this mechanism.

\section{REFERENCES}

1 Orcel P. Hypercalcémie des affections malignes, ed. Masson, 1996

2 Daroszewska A, Bucknall RC, Chu P, Fraser WD. Severe hypercalcemia in B-cell Lymphoma: combined effects of PTH-rp, IL-6 and TNF. Postgrad Med J. 1999

3 Hanihara T, Takahashi T. PTH-rp associated Hypercalcemia in probable intravascular lymphoma of B-cell type. Am J Hematol. 1996

\section{OP0011 CONSTRUCTION OF A PHYSICAL MAP AND IDENTIFICATION OF CANDIDATE GENES FOR FAMILIAL CHONDROCALCINOSIS AT CHROMOSOME 5P15}

${ }^{1} \mathrm{~A}$ Pendleton, ${ }^{1} \mathrm{GD}$ Wright, ${ }^{2} \mathrm{MD}$ Doherty, ${ }^{3} \mathrm{R}$ Shiang, ${ }^{3} \mathrm{~A}$ Hughes. ${ }^{1}$ Rheumatology, Musgrave Park Hospital, Belfast, UK; ${ }^{2}$ Academic Rheumatology, University of Nottingham, Nottingham, UK; ${ }^{3}$ Medical Genetics, Queens University Belfast, Belfast, UK

10.1136/annrheumdis-2001.480

Background A gene for familial chondrocalcinosis was previously mapped to a locus (CCAL2) on chromosome 5p. ${ }^{1}$ The purpose of the study was to identify this gene and investigate its role in 